\title{
Study of Landslide Prone on the Road of Tomohon-Tanawangko in Tomohon City
}

\author{
Denny Maliangkay* \\ Geography Deparment \\ Faculty of Social Sciences, State \\ University of Manado \\ Manado, North Sulawesi \\ dennymaliangkay@unima.ac.id
}

\begin{abstract}
Disaster is a series of events caused by human nature, or both resulting in casualties and human suffering, property damage, environmental damage, damage to infrastructures facilities, and public utilities as well as disturbance of the system raises the life and livelihood. Landslides (landslides) represents a comprehensive disaster in mountainous and hilly regions in the world, has led to loss of life and material damage. Factors causing landslides, among others: rainfall, steep slopes, soils that are less dense and thick, rock is less powerful, the kind of governance of land, vibration, and shrinkage of the water table by or dams, the extra burden, erosion / erosion, the embankment material on the cliff, the former long avalanche, the discontinuity field (field is not continuous), deforestation, waste disposal area. The problem in this research is only limited studies landslide-prone land in the lane Tanawangko-Tomohon Tomohon. Main purpose of this study was to determine the points of land landslide hazard on the road lane Tomohon-Tanahwangko benefits derived from this research is to be produced a study of geological and geomorphological conditions Tomohon-Tanawangko lane road. Variables to be studied, namely landslide, the physical condition of the study area, and the factors triggering the landslide of the most influential land. Identified three types of land landslide that occurred in Tomohon-Tanawangko lane road covering; collapse (fall), landslides (slides), and flow (flow). Avalanche land is most common creep (flow) of seven (7) points avalanches. Land landslide vulnerability study area was divided into four (4) landslide prone zones include; Low Land landslideprone zones, landslide-prone zones Land moderate, high land landslide-prone zones, landslide-prone zones land is very high. Interval slope of each point landslide Land is at $\mathbf{4 4 \%} \mathbf{- 8 5 \%}$, so it can be seen that from every point of avalanches that are in landslide-prone zones landslideprone zones of moderate to very high land.
\end{abstract}

\section{Keywords: Landslide, Disaster, Hazard}

\section{INTRODUCTION}

The need for awareness of that, the Republic of Indonesia including the island nation of active tectonics, volcanic active, wet tropical climate, densely populated by various ethnic groups, so never escape the risk to disasters whether natural or man-made disasters. In other words, anywhere and anytime people in Indonesia are always at risk to disasters, earthquakes, volcanic eruptions, tsunamis, avalanches, floods, droughts, storms, forest fires, and the inter-ethnic violence. Each type has a severe impact of the disaster and resulted in casualties and property losses are not small.

Land landslides (landslides) represents a comprehensive disaster in mountainous and hilly regions in the world, has led to loss of life and material damage.The factors causing landslides, among others: rainfall, steep slopes, soil less dense and thick, less solid rock, the type of land system, vibration, and shrinkage of the water table by or dams, the extra load, abrasion / erosion, their embankment material on the cliff, the former long avalanche, the discontinuity field (field is not continuous), deforestation, waste disposal area

In the event of landslides will disrupt community activities. The most feared again if fatalities due to falling land landslide would have harmed many people both morally and materially.

Based on the background of the above problems, it can be identified several problems:

- In Tomohon Tanahwangko lane road in an area prone to landslide disaster land.

- Lack of attention and concern of the community and government on the condition and quality of land in Tomohon-Tanahwangko lane.

- Steep topography / steep in some point and the high rainfall in the rainy season which causes the occurrence of landslide prone land.

- Avalanche danger due and affects the activities of public land in the lane Tomohon Tanahwangko

\section{Restricting the problem}

The problems that arise in the study are complex, therefore the problem in this research is only limited studies landslide-prone land in the lane Tomohon Tanawangko

\section{Aim}

Main purpose of this study was to determine the points of land landslide hazard on the road lane Tomohon Tanahwangko

\section{Benefits of Research}

This research can directly obtain information for the government and the public about the landslide disaster-prone land in Tomohon Tanawangko lane. While the benefits of 
this research is to be produced a study of geological and geomorphological conditions paths Tomohon Tanawangko.

\section{METHOD}

\section{A. Method}

The method used in this research is qualitative descriptive method with approach overlay or overlaying maps to produce maps prone to landslides.

\section{B. Tools and Materials}

- Clinometer for measuring slope

- Altimeter altitude measurement

- material

- map Slopes

- Geologic map

- Map of Land Use

- Soil map

\section{Research Variable}

In this study the variables that will be studied, namely landslide Land, the physical condition of the study area, and the factors triggering the landslide of the most influential land cover map:

- Climate (rainfall)

- Slope

- land use

- Geology

\section{Data Collection Technique}

This study used two types of data are primary data and secondary data.

1) Primary data Primary data collected among others long slope and slope, land use, soil texture, effective depth / soil, and the primary data will be obtained directly through measurements and observations in the field and see pernelitian previous research-related.

2) Secondary Data Secondary data collected were: Of base maps such as maps geological maps, soil maps, topographical maps and land use maps. The maps obtained from BAPEDA SULUT or other agencies. Rainfall and temperature data obtained through BMKG Kayuwatu Manado.

\section{E. Analyze Data}

The data analysis was done by scoring or dignity as follows:

1) Slope Scaling slope based on the concept that basically affect the slope of the force of gravity and the shear force along the slope. The flatter slope, the force of gravity can work entirely, so that the material will not rot and loose horizontal shift, but on a steep slope incline to the resultant force will occur due to the gravitational force and shear force. Besides flat slope, soil water movement is slower than on a sloping hillside. Based on previous descriptions compiled class scalling slope in the role of determining the level of avalanche danger as can be seen in the table below:

Table 1. Class Scalling Slopes

\begin{tabular}{|l|l|l|l|l|}
\hline No. & Klas & large Slope & criteria Slope & Harkat \\
\hline 1. & I & $0-8 \%$ & Flat & 1 \\
\hline 2. & II & $>8-15 \%$ & Sloping & 2 \\
\hline 3. & III & $>15-25 \%$ & tilt & 3 \\
\hline 4. & IV & $>25-40 \%$ & Steep & 4 \\
\hline 5. & V & $>40 \%$ & very steep & 5 \\
\hline
\end{tabular}

Source: Suprapto Dibyosaputro 1998

2) Land Use Intended land use various forms of human intervention in the use of natural resources for the welfare of mankind. Form and land use such as penterasan, hoeing, planting timber on a slope with a certain slope, which do not follow the rules of conservation, it will create new problems such as landslides. Scalling on land use, as in the following table:

Table 2. Scale Class Land Use

\begin{tabular}{|l|l|l|}
\hline No. & Land Use & Scale \\
\hline 1. & similar forest & 1 \\
\hline 2. & No similar forest & 2 \\
\hline 3. & Plantation & 3 \\
\hline 4. & $\begin{array}{l}\text { Settlements and other supporting } \\
\text { facilities }\end{array}$ & 4 \\
\hline 5. & \multicolumn{1}{|c|}{ Moor } & 5 \\
\hline
\end{tabular}

Source: Suratman W. et al 1992)

3) Vegetation density The density of the vegetation seen from the level of plant density and canopy of leaves. Land covered by closed, failed to give a chance sunlight reaches the ground level so that physical weathering hampered, while land that is not covered by vegetation will occur as the reverse conditions. Scale vegetation density as in the following table:

Table 3. Vegetation density class scalling

\begin{tabular}{|l|l|l|c|}
\hline No. & class density & large density & Scale \\
\hline 1. & cheek by jowl & $75-100 \%$ & 1 \\
\hline 2. & Meeting & $50-75 \%$ & 2 \\
\hline 3. & moderate & $25-50 \%$ & 3 \\
\hline 4. & Rarely & $15-25 \%$ & 4 \\
\hline 5. & Very rarely & $>15 \%$ & 5 \\
\hline
\end{tabular}

Source: Suratman et al (1992)

4) Steep walls conditions Is one of the steep walls of rock types constituent pencerminaan landforms, rock stratigraphic condition constituent, whether in the form of fault tectonic processes and folds, or it may be due to the intensity a notch by surface runoff, which is concentrated in the groove or valley of the river, or also due to human activities. Avalanche relation to land, the steep wall in the region will greatly favor the occurrence of landslide Land. This is due to the steep walls of both faults, folds, incising, will provide an opportunity receive more sunlight so that the weathering will be more intensive. Based on this concept, conceived scalling steep wall condition as shown in Table. below this.

Table 4. Scalling Class Wall Rough

\begin{tabular}{|c|c|c|c|}
\hline No. & $\begin{array}{c}\text { Class Total } \\
\text { Wall Rough }\end{array}$ & $\begin{array}{c}\text { Conditions steep } \\
\text { walls }\end{array}$ & Scale \\
\hline
\end{tabular}




\begin{tabular}{|l|l|l|l|}
1 & $\begin{array}{l}\text { Without - very } \\
\text { little }\end{array}$ & $\begin{array}{l}\text { Valley, the slope } \\
\text { is not steep }\end{array}$ & 1 \\
\hline 2 & a little & $\begin{array}{l}\text { Valley, rather } \\
\text { steep slope }\end{array}$ & 2 \\
\hline 3 & moderate & $\begin{array}{l}\text { Valleys, steep } \\
\text { slope portion }\end{array}$ & 3 \\
\hline 4 & Lots & $\begin{array}{l}\text { Valleys, steep } \\
\text { slopes }\end{array}$ & 4 \\
\hline 5 & Very much & $\begin{array}{l}\text { Valley, very } \\
\text { steep slopes }\end{array}$ & 5 \\
\hline
\end{tabular}

Source: Suratman et al (1992)

\section{RESULT}

\section{A. Description Location Research}

\section{1) Location and Boundaries}

Tomohon-Tanawangko path astronomically located on $1^{\circ} 18^{\prime} \mathrm{LU}$ until $1^{\circ} 23^{\prime} \mathrm{LU}$ and $124^{\circ} 41^{\prime} \mathrm{BT}$ to $124^{\circ} 48^{\prime} \mathrm{BT}$ appearance of the earth covered by maps Manado Sheet No. 2417-23 scale of 1: 50,000 in 1991. The administration is included in two (2) sub-districts and the District of West Tomohon Tombariri covering Woloan, Taratara, Ranotongkor, Lolah, Lemoh, and Sarani, North Sulawesi Province.

- North side adjacent to Mount Lokon, Mount Tatawiran, Gardens Residents and Settlement

- The southern most border Gardens Residents

- East with Tomohon

- West borders with the Capital District Tanawangko, Ranowangko River.

\section{2) Topography}

Study area topography varies from flat to steep, wide area 7001.07 ha with flat or wavy topography (slope $0-8 \%$ ) covering $5 \%$ of the area of research, choppy until the undulating topography (slope> 8-15\%) with an area of 68\% of the research area, the topography is undulating, hilly (slope $>15-25 \%$ ) covering $16 \%$ of the area of research, and the hilly topography with steep slopes (slope> 25-40\%) with an area of $11 \%$ of research area.

\section{3) Climate}

Research areas include areas that have climatic conditions that are influenced by rainfall and temperature parameters. Rainfall according to Mock (1973) can be calculated in a number of wet months, humid months, and a dry month with the following conditions:

- Wet months when monthly rainfall of over $100 \mathrm{~mm}$

- Humid month when the monthly rainfall between $60-100$ $\mathrm{mm}$

- Dry months when the monthly rainfall of less than 60 $\mathrm{mm}$

The research area has an average wet season large enough (9.6 months) and the average small dry months (0.6 months). These conditions will make the study area has a sufficiency of the availability of water, although the water savings are determined by variable soil conditions and existing plants (Tewal, 2001).
Climate classification study area has a value of $\mathrm{Q}=$ $6.25 \%$, which indicates that this type of climate is A or very wet which is obtained from: Climate affects the landslide Land especially rainfall which is one of the factors triggering the occurrence of landslide Land. In this study the relationship between land landslide with rainfall can be seen from some of the events that occurred landslide land in the study area in the landslide area produced 14 points Land. One landslide occurrence land in the study area can be seen in picture

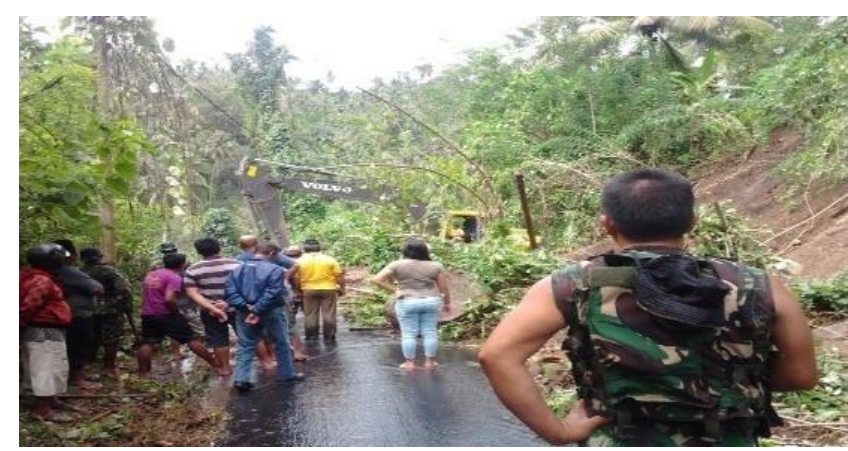

Figure 1. Land landslide incident at one point in the area of research looks bulldozer was cleaning roads

\section{4) Vegetation}

Vegetation (growing - plants) have a relationship with the land cover land landslide symptoms it is because the vegetation enough to affect the pace of surface water and their roots in the soil serves as a binder result of weathering, thus inhibiting or even resist the erosion process. In addition to these uses, vegetation also speeds up the process of formation of the soil body, it is a negative influence inevitable bias towards the stability of the land. In the study area it is seen that much land landslide occurred in the area an area that is rarely bare or overgrown with trees and grass.

\section{5) Soil}

The type of soil found in the study area based on the soil map SULUT in 2011 consisted of soil types and Andosol Alfisol and Alfisol Mollisol. Alfisol soil type has a layer thick enough soil solum is between $90-200 \mathrm{~cm}$, but the boundary between the horizon is not so clear. Soil color is brown to red. Texture is somewhat varied from clay to clay, with a blocky structure bersusut. The content of plant nutrient elements such as $\mathrm{N}, \mathrm{P}, \mathrm{K}$ and $\mathrm{Ca}$ are generally low and the soil reaction $(\mathrm{pH})$ is very high (Sarief, 1985).

Andosol very diverse types of soil, this land can be shaped clay, and the clay coarse texture. Substances contained therein are predominantly volcanic ash from the eruption. The soil types encountered in the area around the volcano, Andisol soil also contains a lot of organic substances contained in the middle and upper layers, while at the bottom of the element content tends sedikit. Types of nutrients Mollisol soil with high organic material, nutrientenriched soil surface (horizon A), usually between $60-80 \mathrm{~cm}$. This soil type has a characteristic soft when dry, dark in color and at least $1 \%$ organic material, base saturation of $50 \%$ or more when measured at $\mathrm{pH} 7$ (Bayu Septianto 2008).

\section{6) Condition Geomorfology}

Geomorphology research area formed by volcanism which was highly influenced by the presence of volcano Lokon, and grouped into three (3) units of landform that slopes are central volcanoes (V2), Slope middle of volcanic strong (V3), and Slope under volcanic denuded (V4). Slope 
unit amid volcanic landforms (V2) has a material with a predominance of loose material ie sand, gravel, and renewal young conglomerates. The process that occurred at the unit are weathering landforms and processes that make up the movement of loose material kovulium formations. In the middle of the volcanic unit Slope landforms strong terdenudasi (V3) and the lower slopes of volcanoes terdenudasi (V4) geomorphological process that develops a negative impact as a result of erosion and avalanches appearance shown by the formation of dense valley on the slopes - the steep slopes. Material contained on steep slopes due to pressure changes that occur either naturally or as a result of anthropic influence becomes stabil. Instability landslide that causes the appearance of land in the study area.

\section{7) Land Use}

Land use in the study area based on land use maps of North Sulawesi in 2011 can be grouped into five (5) main groups namely settlements, agricultural land, dry land agriculture mix, rice paddies and secondary dry forest. The settlements are the research area is an area that is used by local residents as a place for living which includes residential quarters along with home gardens, schools, offices, schools, health centers, restaurants, houses of worship, lodging, stalls and markets. The settlements in the study area occupies the area - an area with a flat slope to slant. Dryland farming in the study area include clove plantations, cocoa plantations, palm, coconut plantations and banana mixture cengki. Plantation - plantation was found on landforms with a gentle slope to steep. The plantation is located on all landforms with a gentle slope to steep. Plantations were found on landforms with steep slopes slope dominated by clove plantations and kelapa.Hal they relate to the treatment plant in order to produce well.The use of land for dryland agriculture intervention in areas of research found only on the slopes of volcanoes amid strong terdenudasi with flat or steep slope. Plants that can be found that is like a banana, maize, ginger, papaya, chili, olive, manga, tomatoes, onions, potatoes and rambutan. Rice fields in the area of research, especially the most adjacent to the road lane Tomohon - Tanawangko only found on Woloan Village, Village Tara-tara. Secondary dry forest located in the study area consists of forests and woods similar kind namely forest and bush mixture. A type of pine forest forested, lantoro forest, and the forest while the teak forests are not similar at all landforms with steep slope up.

\section{8) Geology}

Based on field observations, research local geological conditions described based on the geological map of North Sulawesi in 2011 with a scale of 1: 92.000 (Effendi, 1976) The Silk Road Tanawangko to Tomohon lithologies composed as follows:

- Young volcanic rocks (Qx), which consists of lava, bombs, lapilli and ash: shaping young volcanoes, including Mount Soputan, Mahawu, Mount Lokon, Klabat, Mount Tangkoko, most of which are still active. Lava issued by Soputan and Mount Lokon mainly basalt, while Mahawu and Mount Tangkoko is andesite.

- Tufa Tondano (QTV) consisting of coarse volcanic klastika predominantly andesite, composed rather than angular to angular liability component, tercirikan by numerous pieces of pumice as tuffs, tuff laipili and, breccias.
Based on geological constituent unit, the research areas are formed by two groups of geological structures that Qx and QTV.

\section{9) Hydrology}

Hydrological conditions research area is determined by the condition of surface water and groundwater are influenced by Pengujan season and dry season. Water surface area of study is determined by the presence of three (3) streams, namely; Ranowangko river, Paniki river, and the river Tambala. Ranowangko river flow direction with upstream located on the slopes of Mount Lokon passed three villages include; Woloan, Tara-tara, and Ranotongkor. While the river flow direction through most of the village Ranotongkor Paniki, Lolah Village, Village Lemoh, to empty into the Tanawangko. And lastly the River Tambala the direction of flow through the village empties into Desa Lemoh until Tambala. The research area also contained a spring that once contributed to the magnitude of the flow of the river. There is also the groundwater contained in the study area which is groundwater seepage that occurs in the middle of the transition slopes and slopes down and also at certain locations due to the cutting of the slope to the road lane.

\section{B. Result}

\section{1) Land landslide that occurred in Tomohon-lane road} Tanawangko

Landslide that occurred in lane Tomohon - Tanawangko include avalanche small size, medium size and large size. Land avalanche paths that affect the activity of Tomohon Tanawangko, the morfometry directly measured in the field. landslide morphometric measurement results based on the data in the field can be seen in Table. 5.5. Conditions measurable slope is the slope of the avalanche, not an overall slope of the terrain. Landslides that occur and affect the activity of the pathway Tomohon - Tanawangko (especially above the road) vary from small, medium to large. Measured slope is the slope of the avalanche as a whole has a steep to very steep criteria. Vegetation around landslide Land has a variation of sparse to dense, with the kind of plants that vary from grass to forests.

2) Type of Land landslide that occurred in Tomohonlane road Tanawangko

Based on observations in the study area, there are three types of land landslide namely:

a) Debris / dropping (fall) is a material movement in an upright under the influence of gravity, generally occur on steep cliffs, material moving in free fall, menggelundung or bounce off the cliff. This type of landslide Keterdapatan land covering 5 points, all of which greatly affect traffic conditions around the street. Type of rock debris (rock fall) produces materials such as stones are small, medium, and large. Large rocks that fall can cause severe damage. With the landslide Soil type is the accessibility to rock around the road stopped. As a result, some residents could not indulge as long as a full day, especially for users of motor vehicles.

b) Avalanche (slide) is a sliding movement or fall-out of one or a group of masses of soil and rock down the slope due to gravity as well as by the bedding plane, cracks and fractures. Avalanche mode (slide) can be identified by images of field gelinciran in avalanches. 
c) Flow (Flow) is a type of land landslide that occurs when the land masses move is driven by the water. The flow velocity depends on the slope, volume and water pressure, and type of material. His movement occurs along the valley and is able to reach hundreds of meters away. In some places can be up to thousands of meters, such as watershed areas around the volcano. The flow of this land can be claimed quite a lot. Type of Land landslide that occurred in the study area the flow is only tens of meters away, and fortunately no casualties. The material was taken only in the form of land, so that this type can be classified into type Debris Flow or flow of soil destruction. Land landslide types are often found in the area of research, especially around Tomohon-Tanawangko lane road.

From the results of the observations made, Land landslide that occurred in the study area both types of landslides (slides), flow (flow) and debris / jungkiran (fall), all of which currently amount to 14 points. The dominant type of land landslide occurred in the area of research is the type of flow (flow).

\section{3) Land landslide based on the research variables}

The research variables in this case a parameter in identifying landslide-prone points Land consists of precipitation, slope, land use and geological structure.

a) Rainfall Land landslide that occurred in the study area is one of the causes of rainfall. Rainfall is quite high with an average of 8.8 wet month (calculation, 2018). It makes this region has a very abundant water supply but it also caused the landslide land at some point in the research area. The relationship between rainfall and landslide Land evident during a landslide land at some point in the research area. Some point to experience with the type of land landslide varies the slide, flow, and fall. Moreover, at some point have groundwater conditions were pretty big. The ground water contained in geological formations permeabelnya not capable of storing and moving water in large enough quantities. Causing the water storage overflows and flows to the ground Besides, rainwater that falls onto the surface of the soil is not obstructed by the trees then there was a landslide land with different types at some point in the research area.

b) Slope The slope also have an influence on the occurrence of landslide land at some point in the research area. The influence of slope is evident from the results of field measurement data analysis showed an average slope of 14 point landslide Land is $48.21 \%=21.69^{\circ}$. The slope is very steep with a percentage of $75 \%$ are at a point 5 to the type of land in the form of debris landslide (fall). While the lowest percentage of the slope at a point 14 with the type of flow (flow). Based on the observation and analysis of these data slope $>60 \%$ (very steep) is widely experienced by point-type landslide debris Land (fall) to carry materials such as gravel, stone gravel and boulders from small to large sizes.

c) Land use, land landslide has a fairly close relationship. Moreover, if the terms of the density and type of vegetation cover land located in the study area. The relationship can be seen from the extensive landslide Shareable land based on land use and density and type of vegetation cover land in the study area Most of the experienced landslide point is farm land. Density and types of covered vegetation on land use also affects the land landslide. Land landslide conditions such as length and width of the avalanche affected by vegetation density that is rare to very rare. Land landslide that occurred at any point in any avalanches caused by factors of vegetation. Vegetation at the point of experiencing landslide Land predominantly coconut trees, banana, shrubs, weeds, and grasses. From the condition of vegetation cover is inadequate land are coupled with a slope that is generally a bit steep, then the stability of the land will decrease and eventually expand the avalanche point.

d) Structural Geology, Tomohon-Tanawangko path are in the middle and lower slopes of Mount Lokon (west G. Lokon). Lapukan soil of volcanic unit is in the form of sand, silt clay to sandy brown to gray is somewhat dense to loose, the nest. The geological structure of the region, studies have land contribution to the landslide happened. By looking at the content of lapukan contained in the geological structure it will affect the stability of land and land landslide triggered at some point

4) Land landslide-prone areas in the path of the road Tomohon Tanawangko

Soil type landslide prone zones as follows:

a) Low Land landslide-prone zones, an area that has a low level of vulnerability to experiencing Land landslide. Areas that are included in this zone has a flat topography with a slope of less than $25 \%$. Generally in this zone rarely have land landslide if the slope is not impaired. And if you have the old Land landslide slope has steadily returned. Land use is generally in the form of paddy fields and some settlements. This zone has an area of approximately $5 \%$ of the research area that covers most Tanawangko and some are in Woloan.

b) Land landslide-prone zones being, this area has a moderate impact to happen landslide Land. Areas that are included in this zone has a flat topography through ramps with slope $25 \%$ - 44\%. Land use generally in the form of settlements, farms and forests. This zone occupies about $27 \%$ of the research area.

c) Landslide-prone zones of high land, this area has a high level of vulnerability to happen landslide Land. Land landslide at any time - can occur when rainfall is quite high, especially in areas bordering the river basins and rock unconformity contact. Generally a slope sloping hilly area $45 \%-64 \%$ to steep $(65 \%-85 \%)$. This zone occupies about $19 \%$ of the research area.

d) Land landslide-prone zones is very high, an area that has a very high level of vulnerability to experiencing Land landslide. In this zone of frequent landslide Land. While the new and old Land landslide is still active occur especially if rainfall is quite high. Areas that are included in this zone is an area of steep $(65 \%-85 \%)$ to very steep / almost upright (slope> 85\%). This zone occupies about $49 \%$ of the research area.

Number landslide the most common land in the village of Sarani (Tanawangko) with the type of debris (fall), the type of landslide (slides), and the type of flow (flow) altogether 8 points. In this study identified only the number of points that appear landslide Land at the time of the study. 


\section{CONCLUSION}

\section{A. Conclusion}

Based on research results that have been obtained, it can be summed up as follows:

1) Identified three types of land landslide that occurred in Tomohon-Tanawangko lane road covering; collapse (fall), landslides (slides), and flow (flow). Of the three types of landslide Land Land landslide number of types of the most common is the creep (flow) of seven (7) points avalanches. Each 1 point to be at the limit of the village administration Taratara, 1 point is at Ranotongkor village, 2 points are located in the village Lemoh, and 3 points in the village of Sarani. In addition an average slope of $48.21 \%=21.69$ of the total slope whole point of the research area experiencing land landslide.

2) Based on the parameters that were examined contained significant effect on the incidence of landslide land at any point. High rainfall, slope ranges rather steep to very steep, and the use of land and the density and type of vegetation that is less well be the cause of landslide avalanche land at any point in the study area.

3) Based on the level of vulnerability to land landslide study area was divided into four (4) Land landslide prone zones include; (1) Zone prone to landslide land low with around 5\% of the area of research, (2) Zone prone landslide Land was broadly $27 \%$ of the area of research, (3) Zone prone landslide Land high with an area of $19 \%$ of the area research and, (4) landslide-prone zones is very high land with an area of $49 \%$ of the research area. Interval slope of each point landslide Land is at $44 \%-85 \%$, so it can be seen that from every point of avalanches that are in landslide-prone zones Land landslide-prone zones of moderate to very high land.

\section{B. Recomendation}

Based on the results of the above conclusion, there are several things that can be considered in follow-up research. Based on these ideas, the authors suggest that stated as follows:
1) The need for the manufacture buttress made of cement or concreteto restrain the rate of future rock/soil is unstable in order to anticipate the landslide incident Land worse particularly at vulnerable points landslide Land in TomohonTanawangko lane road.

2) The need for landslide control of land through vegetative approach by preventing water accumulates above the glide plane. Highly recommended plant tree species rooted in, can penetrate the waterproof coating, capable merembeskan water into deeper layers, and has a relatively light mass.

3) Need for the trench (trench) is wide enough to prevent underground water contained in the steep walls that did not get into the flow of the river and then destabilize the ground especially when rainfall is high enough.

\section{REFERENCES}

[1] Annonim Department of Public Works, 1987. "Annual Report". Bandung. Directorate of Geology and Environmental Governance

[2] Department of Public Works, 1981. "Planning and Control Directive landslide Land". Jakarta: Yayasan Publisher PU

[3] Directorate of Environmental Geology, 1997. "Land Movement in Indonesia". Bandung: Ministry of Mines and Energy

[4] Anonymous Crisis Center, 2007. Tackling Natural Disasters. Department of Health

[5] Junun Sartohadi and Elegant S. Pratiwi, 2014 Editor, Flower Disaster Research medley managemen Kelud volcano in eruption crisis period. Student Library Yogyakarta

[6] Kjekstad 2008, Morphometry analysis Slope and Morfostruktur rocks for the Prevention of Landslide in Banjarmangu District of Banjarnegara, Research Report, Surakarta: LPPM-UMS

[7] Selvana .TR Tewal, 2001. "Evaluation of Avalanche Danger Level Land On Line Road Manado-Tomohon, North Sulawesi". Thesis S-2, Yogyakarta UGM Faculty of Graduate Studies

[8] Thornbury, WD, 1958. "Principles of Geomorfphology". London: John Wiley and Sons.Inc

[9] Opinion, 2008, Flood and landslide,http://www.lampungpost.com, accessed on February 28, 2017.

[10] UNDP, the Disaster Management Training Program, Disaster Mitigation, Issue Two, Cambridge http: //mdarmawankenkyu.blogspotcom/2018/1 